\title{
PUBLIC ADMINISTRATION IN DEVELOPMENT OF THE PROCEDURE OF THE SECURING A CLAIM
}

\author{
Andrejs Gvozdevičs \\ Rīga Stradiņš University, Latvia
}

\begin{abstract}
The Ministry of Justice of the Republic of Latvia is a leading public administration in the justice sectors and plays an important role in the development of the procedure of the securing a claim. Topicality and novelty of the research are reflected in the fact that until now in the legal doctrine weren't made depth and extensive researches of the role of public administration in solving problems of the securing a claim. The aim of the research is to carry out an assessment of the activities of the Ministry of Justice in the development of the securing a claim. In the present research, using the analytical, descriptive and deduction/induction method, were analysed the normative acts, legal policy planning documents, annotations of draft amendments to the Civil Procedure Law, etc. Results: actions of the Ministry of Justice to develop the securing a claim sometimes are chaotic. Conclusions: in order to achieve the defined objectives of the institute of the securing a claim, the state should pay attention to the systematic improvement of current civil procedural regulation.
\end{abstract}

Keywords: civil procedure law, government, Ministry of Justice, securing a claim.

\section{Introduction}

Within the framework of his scientific activity, the author conducts a research on the problematic aspects of the process of the securing a claim to allow finding potential solutions and to make the process of the securing a claim more efficient. The Ministry of Justice of the Republic of Latvia is the leading state authority in the field of law, which among other things also develops, organizes and coordinates the state policy in the sphere of procedural rights (By-laws of the Ministry of Justice, 2017), therefore, it undoubtedly plays an important role in the development of the institute of the securing a claim. In the research, topicality and novelty arise from the fact that until now the legal doctrine has not dealt with indepth and extensive problems of the institute of the securing a claim, including the role of public administration in solving these problems.

\section{Aim, Materials and Methods}

The purpose of the research is to evaluate the activity of the Ministry of Justice of the Republic of Latvia in the development of the institute of the securing 
a claim in order to determine its conformity to the purpose and tasks of the legal framework of the securing a claim. Using analytical, descriptive and deduction/induction method, in the present research were analysed the normative acts, legal policy planning documents, annotation of the drafts of the amendments to the Civil Procedure Law (Civil Procedure Law [CPL], 1998), etc.

\section{Historical development of the institute of law - the securing a claim}

The institute of law of the securing a claim has been known already in ancient Roman legal system, where the defendant was required to deposit a guarantee of wealthy persons (cautio judicatum solvi); the defendant had to swear an oath for performance (cautio jurataria) (Bukovskis, 1933).

In the legal system of the Republic of Latvia this institute of law is known since the 1914 Civil Procedure Regulations, which were effective in the Republic of Latvia, based on the Law of the Republic of Latvia "Temporary regulations on the courts of Latvia and procedure of prosecution" of December 6, 1918, pursuant to which Latvian courts had to operate according to the local Russian laws, which were effective in the current territory of Latvia until October 24, 1917 and specified the procedure of the securing a claim to allow the plaintiff to gain satisfaction in the case of satisfying of the claim (Bukovskis, 1933).

The 1914 Civil Procedure Regulations stipulated that the court may ensure securing a claim only on the basis of the request of the involved party during the entire prosecution of the case even in the second instance, but not in the third; the court ruling on claim security could have been appealed with ancillary complaint, which, nevertheless, did not stop the execution of the appealed decision, while the appeal against the decision, which revoked the securing a claim, on the other hand, stopped the execution of this decision on the securing a claim, and the defendant had the rights to reimbursement of damage, if the claim was dismissed and/or if the security was revoked (Bukovskis, 1933).

In 1938 the Civil Procedure Law came into effect in Latvia, where Section 174-177 of the Chapter 6 "Ancillary procedures" stipulated the rights of the plaintiff to submit request for the securing a claim, compliance with which depended on the magistrate, except for the securing a claim based on a duly endorsed bill or protest bill, the magistrate was not entitled to refuse such requests (Civilprocesa likums, 1938).

It follows from the regulatory content of the 1914 Civil Procedure Regulations and the 1938 Civil Procedure Law that the matter on claim security was resolved in a similar manner and with the purpose to protect the plaintiff from the illegal activities of the defendant and to ensure the possibility to gain satisfaction from the defendant's property in case of satisfaction of the claim. 
When comparing the legal framework of the securing a claim of the first Republic of Latvia and the current one, it is clear that a lot has been adopted in the current legal framework from the 1914 Civil Procedure Regulations and the 1938 Civil Procedure Law, except for the archaic forms of claim security such as court guarantee and signature on non-changing of place of residence, but, considering that both the society and the awareness of the people have changed and the legal relations have become more complex, considering the era of the digitalized information, the issue of the development of the institute of the securing a claim to make it an efficient and contemporary one is still valid.

\section{Role of the Ministry of Justice of the Republic of Latvia in the development of the legal framework of the securing a claim}

On October 14, 1998 the Saeima of the Republic of Latvia adopted the new Civil Procedure Law (CPL, 1998), which has come into effect on March 1, 1999 and is still valid with several amendments.

Basic edition of Section 137 of the CPL stipulated that if there are reasonable grounds to believe that enforcement of the court judgment in the case may become problematic or impossible, the court or judge may upon a reasoned application of the plaintiff take a decision to secure a claim. The means of the securing a claim shall be specified in the application of the securing a claim. Claims can be secured only in claims of a financial nature. The securing of a claim is permissible at any stage of the proceedings, as well as before the action is brought in court (CPL, 1998). Such definition of the securing a claim remains unchanged from the date of entry into effect of the CPL. Since the entry into effect of the CPL, the provisions on the securing a claim have been amended and supplemented fifteen times, namely by amendments to the CPL adopted by the Saeima on October 31, 2003, June 19, 2003, February 12, 2004, September 7, 2006, February 5, 2009, August 4, 2011, September 8, 2011 November 29, 2015, April 23, 2015, May 23, 2016, June 1, 2017, March 1, 2018, and once the regulations on the securing a claim were amended by the judgement in the case No 2009-85-01, made by the Constitutional Court on March 30, 2010. Mainly these amendments to the CPL were developed and submitted to Saeima for consideration by the Ministry of Justice of the Republic of Latvia. The purpose of the research was to identify conditions that caused such frequent amending of the legal norms of the securing a claim and to analyse whether such amendments eventually made the institute of the securing a claim as efficient means of procedural protection, therefore attention was paid, in author opinion, to the most significant amendments to the regulations of the securing a claim.

So, in September 7, 2006 the Saeima adopted extensive amendments to the CPL, which came into effect on October 11, 2006, expressing Paragraph 3 of 
Section 137 as follows: "(3) Examination of the issue of securing of a claim may be allowed at any stage of the proceedings, as well as prior to the bringing of court action”, excluding Sections 144, 145 and 146, which defined withdrawal, termination and appeal of the securing a claim in the basic version of the CPL, and also expressing Sections 138, 139, 140, 141 and 142 of the CPL in a new edition, therefore determining forms of means of securing of the claim, conditions of securing a claim before bringing of the court action, procedure of consideration of the application for the securing a claim by the court, appeal of the securing a claim and procedure of execution of the decision on claim security (Grozijumi Civilprocesa likumā, 2006). Upon submitting proposals for these amendments to the Civil Procedure Law, the Ministry of Justice specified that Chapter 19 (Securing a Claim) of the Civil Procedure Law currently fails to have a coordinated used terms, for example, "change of the means of the securing" and "replacement of the means of the securing", as well as terms "withdrawal of the securing a claim" and "termination of the securing a claim". To resolve the issues related to the securing a claim, Chapter 19 of the Civil Procedure Law has been reprocessed in the bill, providing that the court will be given rights at any stage of the proceedings to both secure the claim and to substitute one form of the securing a claim by other ones, and to withdraw the securing a claim (Likumprojekts "Grozījumi Civilprocesa likumā" 3571, 2005).

Considering the judgements of the Constitutional Court that followed these amendments of the Civil Procedure Law, which declared some of the amendments as not conforming to the Constitution, it has to be concluded that the resolution of the issues, related to the securing a claim, intended by the Ministry of Justice, has not succeeded in full, but, considering that these amendments to the Civil Procedure Law are still effective with minor corrections and additions, the issue of improvement of the regulations of the securing a claim is still valid.

On February 5, 2009 the Saeima adopted amendments to the Civil Procedure Law, which came into effect on March 1, 2009 (Grozījumi Civilprocesa likumā, 2009), expressing Article 6 of Paragraph 6 of Section 138 in a new edition, namely, stipulating that the means by which a claim may be secured are "seizure of those payments, which are due from third persons, including monetary funds in credit institutions and other financial authorities", replacing first sentence of Paragraph 4 of Section 140 of the CPL and determining a procedure, in which the court may substitute the means of securing a claim with the seizure of monetary funds, paid into the depositary account of the court bailiff, and also making amendments to the sections of the CPL, which specify appeal of the court rulings, related to the securing a claim: stipulating in Paragraph 5 of Section 140 that securing a claim may be revoked on the grounds of the motivated application of the plaintiff both by the court, which adjudicates the case on the basis of the merits, and specifying in Paragraph 1 of Section 141 that ancillary complaint may 
be filed only in regards to the court decision, by which the means of the securing a claim is substituted by other means of the securing a claim, regards to the court decision, by which the application on the securing a claim is dismissed, and in regards to the court decision, by which the plaintiff has to reimburse the losses, whereas in Paragraph 2 of Section 141 of the CPL is it specified that if the decision on the securing a claim is made in the absence of the party of the case, then the term for the submission of ancillary complaint shall be counted from the day of issuing of the decision, instead of the day of receiving of the decision. Paragraph 1 of Section 142 of the CPL was supplemented with the regulation, that a decision to secure a claim and a decision to withdraw securing a claim shall be enforced immediately after it is made. Taking into account the aforementioned new regulation in Paragraph 1 of Section 142 of the CPL, the sentence of Paragraph 1 of Section 142 of the CPL, which specified that submitting of ancillary claim on this decision shall not stop its enforcement, was excluded. By expressing Paragraph 5 of Section 142 of the CPL in a new edition, the Saeima has determined that, by seizing the payments, those payments, which are due from third persons to the defendant, these amounts shall be seized in the amount of the claim, in compliance with the restriction, specified in Article 3 of Annex 1 of this Law in regards to the debtor, i.e., money in the amount of the minimum monthly wage for the debtor, each member of his or her family and persons dependent on the debtor, but in cases regarding the recovery of maintenance for the support of minor children or for the benefit of the Administration of Maintenance Guarantee Fund administration - money in the amount of 50 per cent of the minimum monthly wage for the debtor, each member of his or her family and persons dependent on the debtor shall not be subject to recovery. Whereas Paragraph 9 of Section 142 of the CPL was supplemented with the sentence that "the sum that has been paid into the bailiff's deposit account as means of securing a claim shall be repaid by the bailiff only on the basis of a court ruling”. Section 568 of the CPL was supplemented with Paragraph 6, specifying that costs related to the decision of the court to secure a claim, to specify means of provisional remedy shall be covered by the plaintiff (Grozijumi Civilprocesa likumā, 2009). Upon submitting of the proposals for these amendments of the law, the Ministry of Justice specified in the annotation of the bill that the question of the rights of the defendant to file an ancillary complaint of the court decision on the securing a claim is still valid in the legal practice; by different interpretation of the existing regulations (second sentence of Paragraph 1 of Section 142, Paragraph 1 of Section 141 in relation to Paragraph 2 of Section 140 of the CPL) different courts decide differently whether a defendant can appeal against a court decision granting an application for security. This results in inequality and violates the right of individuals to a fair trial, which is unacceptable (Likumprojekts "Grozījumi Civilprocesa likumā” Nr: 826/Lp9, 2008). 
As can be seen from the amendments made to the Civil Procedure Law, the possibility of appeal against ancillary claim and related issues has been significantly reduced, and the Ministry of Justice's objective of eliminating inequalities in the rights of the parties to appeal the court decision related to the securing a claim was not achieved.

On March 30, 2010 the Constitutional court Of the Republic of Latvia made a decision in the case No 2009-85-01 "Conformity of Paragraph 1 of Section 141 of the Civil Procedure Law, to the extent as it does not provide for the right to submit an ancillary complaint regarding the compliance of the decision satisfying the application for securing a claim, to Section 91 of the Constitution, which determines, that: 'all human beings in Latvia shall be equal before the law and the courts. Human rights shall be realised without discrimination of any kind", Section 92 of the Constitution, which determines, that: ''everyone has the right to defend his or her rights and lawful interests in a fair court. Everyone shall be presumed innocent until his or her guilt has been established in accordance with law. Everyone, where his or her rights are violated without basis, has a right to commensurate compensation. Everyone has a right to the assistance of counsel", and Section 105 of the Constitution, which determines, that: 'everyone has the right to own property. Property shall not be used contrary to the interests of the public. Property rights may be restricted only in accordance with law. Expropriation of property for public purposes shall be allowed only in exceptional cases on the basis of a specific law and in return for fair compensation') (Latvijas Republikas Satversme, 1922), where among other things it was established, that:

- The right to have a claim secured is an important procedural right that can be exercised by the plaintiff at any stage of the proceedings, as well as before any action is brought in court. Securing of a claim and resolution of issues related thereto is an essential part of civil procedure, which, like civil procedure as a whole, must comply with the requirements of Section 92 of the Constitution. Consequently, the court must take decisions on issues of the securing a claim in accordance with the procedural order, which complies with Section 92 of the Constitution.

- Equality of procedural rights is an essential element of the right to a fair trial and a specific expression of the principle of legal equality.

- As the legal proceedings may last for several years, the right to claim damages after the judgment has become effective may often prove ineffective.

- $\quad$ The view that the defendant's right under Paragraph 5 of Section 140 of the Civil Procedure Law to apply for withdrawal of the securing a claim 
to the court that has granted the securing a claim is equivalent to the right to file an ancillary complaint, cannot be accepted either.

- The plaintiff and the defendant are not set in an unequal situation in the proceedings, adjudicating the securing a claim. This limits the equality of procedural rights inherent in the right to a fair trial.

- In order for the restriction of fundamental rights to comply with the Constitution, it must be established by law, justified by a legitimate aim, as well as proportionate or commensurate to this aim. It is also stated in the scientific literature that derogations from the principle of equality between the parties are permissible only if they are objectively and reasonably justified (Torgāns, 2006).

- According to the Constitutional Court, the current legal framework, which prohibits the defendant from appealing against the decision granting the application for securing the claim or the decision rejecting the application for the withdrawal of the claim, does not balance two essential and interrelated elements of Section 92 of the Constitution procedural economy and equality of procedural rights.

On the basis of the above-mentioned reasoning, the Constitutional Court has, inter alia, ruled: to declare Paragraph 1 of Section 141 of the Civil Procedure Law to the to the extent as it does not provide for the right to submit an ancillary complaint regarding the compliance of the decision satisfying the application for securing the claim, as non-compliant with Section 92 of the Constitution of the Republic of Latvia (Satversmes tiesas spriedums lietā Nr. 2009-85-01, 2010).

On August 4, 2011 the Saeima adopted amendments to the Civil Procedure Law, which came into effect on October 1, 2011, expressing title of Section 137 (Grounds for Securing a Claim and Contents of an Application) and first paragraph in new edition, specifying the details of the application for the securing a claim. In addition Paragraph 1 of Section 140 was supplemented with the following sentence: "In deciding an issue regarding securing of a claim, a court or judge shall take into account prima facie formal legal grounds" and first sentence of Paragraph 1 of Section 141 was expressed as follows: "An ancillary complaint may be submitted regarding the decision referred to in Section 140, Paragraph three of this Law, decision by which the application for withdrawal of securing a claim is refused, and also for the court decision to secure losses which could be incurred by the defendant in relation to securing a claim”; Section 143 was supplemented, specifying that the defendant is entitled to demand compensation for losses he or she has incurred due to the securing of the claim if securing of the claim has been withdrawn in the case laid down in Section 140, Paragraph eight of this Law” (Grozījumi Civilprocesa likumā, 2011). 
Upon submitting of the proposals for these amendments of the law, the Ministry of Justice specified that a term should be defined in the Civil Procedure Law, when the day of the court hearing is due to be scheduled for the deciding on the applications, specified in Paragraph 3 and 5 of Section 140 of the Civil Procedure Law. Section 143 of the Civil Procedure Law states that the defendant is entitled to demand compensation for losses he or she has incurred due to the securing of the claim if securing of the claim raised against him has been dismissed. Therefore Section 243 of the Civil Procedure Law shall be supplemented with a regulation, which specifies the rights to claim reimbursement of losses, which have resulted due to the securing a claim also in cases, if the claim has been left without adjudication or if the legal proceedings have been suspended (Likumprojekts "Grozījumi Civilprocesa likumā” Nr.:11/Lp10, 2010).

On September 11, 2014 the Saeima adopted amendments to the Civil Procedure Law, which came into effect on November 1, 2014, supplementing Section 138 with Paragraph 7. ${ }^{1}$ as follows: " $\left(7^{1}\right)$ seizing of those payments, which are due from third persons, including monetary funds in credit institutions and other financial authorities, shall not be permissible in claims where the compensation, which is to be determined on the basis of the discretion of the court, is claimed", updating the form of arbitration court in Section 139 as "permanent, therefore determining that if the parties have agreed to submit the dispute to a permanent arbitration court, an application shall be submitted to a court based on the location of the debtor or his or her property (Paragraph 2 of Section 139 of the CPL), and also in satisfying an application for securing a claim before an action is brought, a judge shall set a time period for the plaintiff within which he or she must submit a statement of claim to the court or permanent arbitration court (Paragraph 3 of Section 139 of the CPL). Paragraph 1 of Section 140 of the Civil Procedure Law was supplemented with the claim for the court, in deciding an issue regarding securing of a claim, to take into account also the proportionality between legal interests of the parties, whereas Paragraph 5 of Section 140 of the Civil Procedure Law was supplemented with the sentence that "when deciding an issue regarding withdrawal of the securing a claim, the court or judge shall evaluate the conditions indicated in Paragraph one of this Section, taking into account evidence and justification submitted by the party”, i.e., the prima facie formal legal grounds of the claim and the proportionality between legal interests of the parties (Grozījumi Civilprocesa likumā, 2014).

Upon submitting of the proposals for these amendments of the law, the Ministry of Justice has not indicated the necessity to amend the sections of the Civil Procedure Law, which concern the securing a claim (Likumprojekts "Grozījumi Civilprocesa likumā" Nr: 1038/Lp11, 2013), but these amendments were developed and submitted for approval during the consideration of the bill 
draft by the Legal Commission of the Saeima (Likumprojekts "Grozìjumi Civilprocesa likumā” Nr: 1038/Lp11, 2014).

On April 23, 2015 the Saeima adopted amendments to the Civil Procedure Law, which came into effect on May 26, 2015, supplementing Section 140 with Paragraph 3. ${ }^{1}$ as follows: " $\left(3^{1}\right)$ When satisfying an application for the replacement of means for securing a claim with other means, the court may repeatedly take a decision on the obligations imposed on the plaintiff in accordance with Paragraphs two and 5.1 of this Section."; supplementing Paragraph 5 of Section 140 of the CPL with the sentence as follows: "In the application the defendant may include a justification for losses incurred due to the means applied for securing a claim or which might be incurred, if the means for securing a claim is not withdrawn."; supplementing Paragraph $5 .{ }^{1}$ of Section 140 of the CPL as follows: "(5) In rejecting an application for the withdrawal of the securing of a claim, the court or judge may concurrently impose an obligation on the plaintiff to ensure the losses referred to in Paragraph five of this Section, by paying the amount laid down by the court in the deposit account of the bailiff within 20 days after the day of taking a decision."; supplementing Section 140 of the CPL with Paragraph 10 as follows: "(10) If in a decision, which is taken regarding an application for withdrawal of the securing of a claim, the fulfilment of obligation laid down in Paragraph 5.1 of this Section is assigned to the plaintiff, however it has not been fulfilled and the plaintiff has not submitted to the court a certification issued by the bailiff regarding payment of the amount into his deposit account, the court or judge shall take a decision to withdraw means for securing a claim."; expressing title of Section 141 of the Civil Procedure Law as follows: "Section 141. Notification and Appeal of Decisions Taken Regarding Securing of Claim Issues”; supplementing Paragraph 1 of Section 141 of the Civil Procedure Law with words and numbers "and also for the court decision to secure losses which could be incurred by the defendant in relation to securing a claim (Section 140, Paragraphs two, 3.1 and 5.1)"; excluding the second sentence of Paragraph 1 of Section 141 of the CPL 141 (In the case, specified in Paragraph 2 of Section 140 of this Law ancillary complaint may be submitted for the court decision in the part, in which the plaintiff is required to reimburse the losses.); supplementing Section 141 of the Civil Procedure Law with Paragraph $1 .^{1}$ as follows: “( $\left.1^{1}\right)$ A decision, which is taken regarding securing of losses that the defendant might incur in relation to securing of a claim, shall be notified to the defendant after the plaintiff has paid the amount laid down by the court or judge to the deposit account of the bailiff" (Grozījumi Civilprocesa likumā, 2015).

Upon submitting of the proposals for these amendments of the law, the Ministry of Justice did not indicate in the annotation of the bill the necessity to amend the sections of the $\backslash$ Civil Procedure Law related to the regulations on the securing a claim (Likumprojekts "Grozijumi Civilprocesa likumā” Nr: 129/Lp12, 
2014), the aforementioned amendments of the Civil Procedure Law have appeared only during the during the passing of the bill for the second reading of the Saeima (Likumprojekts “Grozījumi Civilprocesa likumā” Nr: 129/Lp12, 2015).

\section{Conclusions}

As can be seen, the institute of the securing a claim is constantly being supplemented and amended, both systematically when the bill is drafted and submitted by the Ministry of Justice, and by supplementing another Civil Procedure Law bill submitted by the Ministry of Justice with amendments to the institute of the securing a claim already while the bill is being considered by the Saeima, and often the bills were submitted by the Ministry of Justice without annotations, despite extensive and substantial amendments to the regulations on the securing a claim, which do not indicate that the bill is serious and prepared in accordance with the principle of good legislation, if the bill is referred to the Saeima without appropriate annotation and explanation. Such sometimes chaotic action to modify the institute of the securing a claim raises a logical issue whether the state in the person of the Ministry of Justice is aware of the current issue of the institute of the securing a claim and purposefully plans to develop the institute of the securing a claim or merely responds to secondary casus. For example, there is still ineffective regulation whereby the defendant has the right to apply for the securing a claim to be filed with the court which made the decision on the securing a claim and, if the application is dismissed, to file an ancillary complaint against it. Such arrangements do not contribute to procedural economy as a two-step appeal system is in place to foreclose the claim, but this process can be reduced to one instance dealing with an ancillary appeal against the decision granting the claim. The Action strategy 2018-2020 of the Ministry of Justice (Tieslietu ministrijas darbības stratēgija 2018-2020.gadiem, 2018) contain no indications that any improvements of the legal framework will be made in this issue. As a result, due to constant amending the regulations of the securing a claim are heavy and contradicting, therefore the activity of the Ministry of Justice in the development of the institute of the securing a claim cannot be rated as successful and satisfying, and the question of the modernization of the legal framework of the securing a claim is still valid.

In order to achieve the defined objectives of the institute of the securing a claim, the state should pay particular attention to the systematic improvement of current civil procedural regulation in order to the securing a claim become genuine procedural protection mean. 


\section{References}

Bukovskis, V. (1933). Civilprocesa mācību grāmata. Rīga., Autora izdevums. Pieejams https://dspace.lu.lv/dspace/handle/7/1282

By-laws of the Ministry of Justice. (2017). Republic of Latvia Cabinet Regulation No. 474. Adoption 16.08.2017. Retrieved from https:/likumi.lv/ta/en/en/id/292913-by-laws-ofthe-ministry-of-justice

Civilprocesa likums. (1998). Latvijas Republikas likums. Adoption: 14.10.1998. Pieejams https://likumi.lv/doc.php?id=50500

Civilprocesa likums. (1938). Latvijas Republikas likums. Grāmata: Civilprocesa likums (1938.g. izd., 1939.iespied.) ar paskaidrojumiem no Latvijas Senata un Tiesu palatas spriedumiem un no attiecīgās zinātniskās literatūras, kā arī dažiem aizrādījumiem uz likumdošanas momentiem. Sast. Konradi, F., \& Zvejnieks, T. u.c. Rīga: Valsts tipogrāfija.

Grozījumi Civilprocesa likumā. (2006). Latvijas Republikas likums. Adoption: 07.09.2006. Pieejams https://likumi.lv/ta/id/144415-grozijumi-civilprocesa-likuma

Grozījumi Civilprocesa likumā. (2009). Latvijas Republikas likums. Adoption: 5.02.2009. Pieejams https://likumi.lv/ta/id/188235-grozijumi-civilprocesa-likuma

Grozījumi Civilprocesa likumā. (2011). Latvijas Republikas likums. Adoption: 04.08.2011. Pieejams https://likumi.lv/ta/id/234862-grozijumi-civilprocesa-likuma

Grozījumi Civilprocesa likumā. (2014). Latvijas Republikas likums. Adoption: 11.09.2014. Pieejams https://likumi.lv/ta/id/269191-grozijumi-civilprocesa-likuma

Grozījumi Civilprocesa likumā. (2015). Latvijas Republikas likums. Adoption: 23.04.2015. Pieejams https://likumi.lv/ta/id/273940-grozijumi-civilprocesa-likuma

Likumprojekts “Grozījumi Civilprocesa likumā" 3571. (2005). Latvijas Republikas Saeima. Pieejams https://www.saeima.lv/L_Saeima8/lasa-dd=LP1556_0.htm

Likumprojekts “Grozijumi Civilprocesa likumā” Nr: 826/Lp9. (2008). Latvijas Republikas Saeima. Pieejams http://titania.saeima.lv/LIVS/SaeimaLIVS.nsf/webSasaiste?Open View\&restricttocategory $=826 / \mathrm{Lp9}$

Likumprojekts "Grozījumi Civilprocesa likumā” Nr.:11/Lp10. (2010). Latvijas Republikas Saeima. Pieejams http://titania.saeima.lv/LIVS10/SaeimaLIVS10.nsf/webSasaiste? OpenView\&restricttocategory=11/Lp10

Likumprojekts “Grozījumi Civilprocesa likumā” Nr: 1038/Lp11. (2013). Latvijas Republikas Saeima. Pieejams http://titania.saeima.lv/LIVS11/SaeimaLIVS11.nsf/webSasaiste? OpenView\&restricttocategory=1038/Lp11

Likumprojekts “Grozījumi Civilprocesa likumā” Nr: 1038/Lp11. (2014). Latvijas Republikas Saeima. Pieejams http://titania.saeima.lv/LIVS11/saeimalivs11.nsf/0/215C0F6794472 B20C2257D49004AFE6C?OpenDocument

Likumprojekts "Grozījumi Civilprocesa likumā" Nr: 129/Lp12. (2014). Latvijas Republikas Saeima. Pieejams http://titania.saeima.lv/LIVS12/SaeimaLIVS12.nsf/webSasaiste? OpenView\&restricttocategory=129/Lp12

Likumprojekts “Grozījumi Civilprocesa likumā" Nr: 129/Lp12. (2015). Latvijas Republikas Saeima. Pieejams http://titania.saeima.lv/LIVS12/SaeimaLIVS12.nsf/0/44718FF313 C0A77AC2257DE10046D28A?OpenDocument

Latvijas Republikas Satversme. (1922). Latvijas valsts likums. Adoption: 15.02.1922. Pieejams https://likumi.lv/doc.php?mode=DOC\&id=57980

Satversmes tiesas spriedums lietā Nr. 2009-85-01. (2010). Latvijas Republikas Satversmes tiesa. Pieejams https://www.satv.tiesa.gov.lv/cases/?search[number]=2009- 85-01 
Gvozdevičs, 2020. Public Administration in Development of the Procedure of the Securing a Claim

Tieslietu ministrijas darbības stratēgija 2018-2020.gadiem (2018). Latvijas Republikas Tieslietu ministrija. Pieejams https://www.tm.gov.lv/lv/ministrija/ricibas-plans-vadibasdokumenti/tieslietu-ministrijas-darbibas-strategija

Torgāns, K. (2006). Civilprocesa likuma komentāri. Trešais papildinātais izdevums. Rīga: Tiesu namu. 